\title{
Determinants of Drug-Induced Hepatotoxicity Among Patients with Human Immunodeficiency Virus Taking a High Dose of Rifapentine Plus Isoniazid Drugs at the All Africa Leprosy Tuberculosis Rehabilitation and Training Center in Addis Ababa, Ethiopia [Retraction]
}

\author{
Lisanwork Arage L, Deybasso HA, Yilma Gebremichael \\ D, Gintamo Nuramo B, Negash Mekuria Z. HIV AIDS \\ (Auckl). 2021;13:307-314.
}

The Editor-in-chief and Publisher of HIV/AIDS - Research and Palliative Care wish to retract the published article. Following publication, the journal was notified that the data for this article was taken from a study funded by USAID and sponsored by the KNCV/Aurum Institute as part of a multi-country clinical trial conducted in South Africa, Mozambique and Ethiopia. The data presented in the article was used by the authors without authorization from the data owners. It also came to the journal's attention that aside from the first author, none of the remaining authors listed were part of the project investigation team and none were known to the principal investigator and had no involvement with the clinical trial.

The authors wish to apologise for this and agree with the decision to retract the article.

Our decision-making was informed by our policy on publishing ethics and integrity and the COPE guidelines on retraction.

The retracted article will remain online to maintain the scholarly record, but it will be digitally watermarked on each page as "Retracted".
HIV/AIDS - Research and Palliative Care is an international, peerreviewed open-access journal focusing on advances in research in HIV, its clinical progression and management options including antiviral treatment, palliative care and public healthcare policies to control viral spread. The manuscript management system is completely online and includes a very quick and fair peer-review system, which is all easy to use. Visit http://www.dovepress.com/testimonials.php to read real quotes from published authors. 